\title{
Karakteristik Manuver dengan Variasi Sudut Kemudi Kapal Ro-Ro
}

\author{
I Made Alet ${ }^{1 *}$, Andi Haris Muhammad ${ }^{1}$, Daeng Paroka ${ }^{1}$ \\ Departemen Teknik Perkapalan, Fakultas Teknik, Universitas Hasanuddin \\ J1. Poros Malino km.6, Bontomarannu, Kabupaten Gowa, Sulawesi Selatan 92171 \\ *Email: alet.santoso@gmail.com
}

DOI: 10.25042/jpe.112018.12

\begin{abstract}
Abstrak
Secara prinsip ada tiga gerakan kapal yang tidak dapat direspon oleh kapal yaitu gerakan Surging, Swaying dan Yawing. Untuk mengendalikan gerakan ini diperlukan Maneuver kapal. Kemampuan maneuver sangat menentukan keselamatan kapal, khususnya saat kapal beroperasi diperairan terbatas atau beroperasi disekitar pelabuhan, oleh karena IMO (International Maritime Organization) telah mensyaratkan sejumlah kriteria standar keselamatan kapal diantaranya adalah Turning Ability dan Course Keeping-Yaw Checking Ability. Dalam paper ini dibahas pengujian model simulasi manuver dengan variasi sudut kemudi kapal jenis Roll-on Roll-off (Ro-Ro) twin rudder dan twin propeller yang dilakukan di Bridge Simulator Politeknik Pelayaran Barombong dengan menggunakan metode software Polaris Ship's Bridge SimulatorKongsberg. Pengujian simulasi ini dapat memprediksi kemampuan manuver kapal pada tahap kompetensi khususnya bagi para operator kapal. Hasil respon kapal pada self turning basin ke kanan menunjukkan bahwa pada kemudi kanan, dengan memposisikan sudut kemudi pada arah kanan dapat mengurangi Rate of Turn, memperlambat waktu putar, menambah kecepatan kapal dan memperpanjang jarak putar kapal, sebaliknya memposisikan sudut kemudi pada arah kiri dapat menambah Rate of Turn, mempercepat waktu putar, mengurangi kecepatan kapal dan memperpendek jarak putar kapal. Simulasi turning basin kanan yang baik adalah yang menunjukkan Rate of Turn tertinggi, kecepatan kapal terendah serta waktu dan jarak putar yang terpendek.
\end{abstract}

\begin{abstract}
Maneuvers Simulation Model with Rudder Angle Variation of the Ro-Ro Vessel. Basically, there are three movements of ship that can't be responded by ship those are surging, swaying and yawing movements. To control this movement, ship maneuvers are required. Maneuverability will deter mind the safety of ships, operate on the restricted water or the ship operated in harbour, because of IMO (International Maritime Organization) has imposed some at criteria for standard safety of ship, between other things Turning Ability and Course Keeping-Yaw Checking Ability. In this paper talking about the test of maneuver simulation model with variations of twin rudder and twin propeller types of roll-on roll-off (Ro-Ro) vessels in that did in Barombong Maritime Polytechnique Bridge Simulator, by using software Polaris Ship Simulator Kongsberg method. The test of this simulation will predict the ability of ships maneuver in the competence phase, especially for the ship operators. Respond result of the ship to the starboard in the self turning should in that the rudder angle in the starboard direction can reduce the rate of turn and slow down the turning time, increase the speed of ship and increase the turning distance of the ship, otherwise to direct the rudder angle to the port can increase the rate of turn, increasing the turning time, reducing the speed of ship, and reducing the turning distance of ship. The right characteristic starboard turning basin simulation shows the fast rate of turn, the shortest speed, time and turning distance of ship.
\end{abstract}

Kata Kunci: Maneuvers, rudder angles, simulator

\section{Pendahuluan}

Tiga gerakan kapal yang tidak dapat direspon kapal adalah Surging, Swaying dan Yawing, untuk mengendalikan gerakan itu diperlukan maneuver kapal. Secara prinsip faktor dari dalam kapal yang mempengaruhi manuver kapal adalah rancangan kapal yang bersifat tetap seperti bentuk kapal, jumlah mesin, propeller, bentuk dan ukuran kemudi, dan yang bersifat tidak tetap seperti sarat, trim, keadaan pemuatan serta teritip, serta faktor dari luar kapal seperti angin, gelombang, dalam dan lebarnya perairan.

Menurut M. Ridwan Utina [1] dalam penelitian tentang Simulasi Manuver Turning Kapal Ferry Penumpang dengan metode simulasi numerik dengan menggunakan software maneuver SURIM pada tahapan desain menyimpulkan bahwa kemampuan merubah lintasan (course 
changing ability) kapal sangat baik kerena nilai rasio advanced/LPP pada sudut kemudi $35^{\circ}$ adalah 3.38, nilai tersebut lebih kecil dibandingkan dengan nilai yang direkomendasikan IMO 4.5, nilai rasio tactical diameter/LPP adalah 1.67, rasio ini jauh lebih kecil dari yang direkomendasikan IMO yaitu 5.0.

Sedangkan menurut Daeng Paroka [2] dalam penelitian Kemampuan Manuver Kapal dengan Sarat Kecil pada Kecepatan Angin Konstan bahwa gaya dan momen yang ditimbulkan oleh arah data angin terhadap kapal yang divariasikan mulai dari $0^{\circ}$ sampai $180^{\circ}$ yang disimulasikan dengan model matematika, mengakibatkan kecepatan operasi kapal berkurang secara drastis, sudut geser yang besar serta sudut kemudi yang besar untuk mempertahankan arah gerak kapal.

Kriteria standar keselamatan kapal [3] untuk Turning Ability dan Course Keeping-Yaw Checking Ability sesuai yang dipersyaratkan oleh International Meritime Organization (IMO) khususnya bagi para operator kapal untuk Pemanfaatan Simulator Dalam Meningkatkan Pengetahuan dan Keterampilan Bernavigasi [4] pada tahap kompetensi diperlukan pengujian model simulasi manuver dengan variasi sudut kemudi dengan menggunakan kapal jenis Ro-Ro twin rudder dan twin propeller model RORO04L [5] dengan metode software Polaris Ship's Bridge Simulator-Kongsberg [6].

Adapun tujuan dari simulasi ini adalah untuk mengetahui seberapa besar pengaruh sudut kemudi kapal saat manover pada bridge simulator dan mengetahui karakteristik kapal yang menunjukkan waktu manuver terhadap gerakan Surging, Swaying dan Yawing.

\section{Metode Penelitian}

\subsection{Data Penelitian}

Pada penelitian ini data kapal yang digunakan pada bridge simulator adalah jenis kapal Ro Ro.

- Data deskripsi kapal model

Data deskripsi kapal model dapat dilihat pada Tabel 1.
Tabel 1. Deskripsi kapal model

\begin{tabular}{|c|c|}
\hline Item & Dimensi \\
\hline \multicolumn{2}{|l|}{ Hull } \\
\hline Deadweight $(D W T)$ & $4,659(t)$ \\
\hline Displacement & $11,070.0(t)$ \\
\hline Length overall (LOA) & $142.0(\mathrm{~m})$ \\
\hline Length between perpendicular (LBP) & $132.0(\mathrm{~m})$ \\
\hline Breadth $(B)$ & $21.0(m)$ \\
\hline Block coefficient & 0.649 \\
\hline Draught fore $(D)$ & $5.90(m)$ \\
\hline Draught aft $(D)$ & $6.10(\mathrm{~m})$ \\
\hline Ship speed (Vs) (Max/Average) & 20.0 (knots) \\
\hline \multicolumn{2}{|l|}{ Engine } \\
\hline Engine Number & $2 P c s$ \\
\hline Total Shaft Power & $12,948(k W)$ \\
\hline Revolution & $550(R P M)$ \\
\hline \multicolumn{2}{|l|}{ Propeller } \\
\hline Number of Propeller & $2(P c s)$ \\
\hline Blades & $4(P c s)$ \\
\hline Diameter & $4.30(m)$ \\
\hline Pitch Ratio & $0.876(P / D)$ \\
\hline Pitch Rate & $0.43(\mathrm{~m} / \mathrm{rev} / \mathrm{s})$ \\
\hline Revolutions & $165(R P M)$ \\
\hline \multicolumn{2}{|l|}{ Rudder } \\
\hline Rudder Number & $2(P c s)$ \\
\hline Range & $-35^{\circ} \&+35^{\circ}$ \\
\hline
\end{tabular}

- Simulasi manuver kapal model

- Manuver turning cycle

Turning Cycle dilakukan saat kapal model bergerak maju/lurus pada kecepatan maksimum 20 knots dengan haluan kearah utara atau pada heading $0^{\circ}$, pengujian Turning cycle pertama dengan kedua kemudi dicikar ke kanan atau pada sudut kemudi $+35^{\circ}$, dan pengujian kedua pada sudut kemudi $+20^{\circ}$ dengan kecepatan maksimum, sampai kapal melakukan turning cycle lebih dari $540^{\circ}$. 
- Manuver zig-zag

Pengujian pertama zig-zag $20^{\circ} / 20^{\circ}$ dilakukan saat kapal model bergerak maju/lurus pada kecepatan maksimum 20 knots dengan haluan kearah utara atau pada heading $0^{\circ}$, kemudian kemudi diarahkan pada sudut $20^{\circ}$ ke kiri dengan kecepatan maksimum hingga haluan kapal mencapai heading $340^{\circ}$ selanjutnya kemudi diarahkan ke kanan dengan kecepatan hingga pada sudut $20^{\circ}$, hingga haluan kapal menunjukkan heading $20^{\circ}$. Pengujian maksimal kedua zig-zag $10^{\circ}$ $/ 10^{\circ}$ dilakukan saat kapal model bergerak maju/lurus pada kecepatan maksimum 20 knots dengan haluan kearah utara atau pada heading $0^{\circ}$, kemudian kemudi diarahkan pada sudut $10^{\circ}$ ke kiri dengan kecepatan maksimum hingga haluan kapal mencapai heading $350^{\circ}$ selanjutnya kemudi diarahkan ke kanan dengan kecepatan maksimal hingga pada sudut $10^{\circ}$, hingga haluan kapal menunjukkan heading $10^{\circ}$.

\section{- Manuver self turning basin}

Simulasi Manuver Self Turning Basin dilakukan dari kondisi kapal diam (0 knot) pada heading $0^{\circ}$. kemudian memutar kapal ke kanan dengan cara Port side Engine Full Ahead dan Starboard side Engine Full Astern (rpm konstan), hingga heading mencapai $180^{\circ}$, dengan beberapa variasi sudut kemudi, yaitu :

a) Variasi I

Variasi sudut kemudi dimana kemudi kiri (P) diposisikan pada sudut $0^{\circ}$ dan kemudi kanan (S) yang divariasikan pada sudut $0^{\circ},+15^{\circ},+30^{\circ},-15^{\circ}$, dan $-30^{\circ}$.

b) Variasi II

Variasi sudut kemudi dimana kemudi kiri (P) diposisikan pada sudut $15^{\circ}$ dan kemudi kanan (S) yang divariasikan pada sudut $0^{\circ},+15^{\circ},+30^{\circ},-15^{\circ}$, dan $-30^{\circ}$.

c) Variasi III

Variasi sudut kemudi dimana kemudi kiri (P) diposisikan pada sudut $30^{\circ}$ dan kemudi kanan (S) yang divariasikan pada sudut $0^{\circ},+15^{\circ},+30^{\circ},-15^{\circ}$, dan $-30^{\circ}$.

\subsection{Analisis dengan Software Polaris Ship's Bridge Simulator-Kongsberg}

Pada penelitian ini software yang digunakan adalah software Polaris Ship's Bridge SimulatorKongsberg dimana seluruh sistem kerja dan kelengkapan dibuat menyerupai seperti kondisi diatas kapal untuk mengetahui repon kapal terhadap manover. kotak dialog kapal model muncul ketika salah satu sub-perintah dari perintah model dari menu kapal model yang dipilih. Lembar Model hanya untuk informasi tentang masing-masing kapal model, dan tidak memungkinkan untuk interaksi operasional.

\section{Hasil dan Pembahasan}

\subsection{Hasil Pemodelan Simulasi Turning Cycle}

Pada proses simulasi turning cycle pertama dengan sudut kemudi $+35^{\circ}$ pada Gambar 1 , menunjukkan perubahan pergerakan respon kapal dari heading $0^{\circ}$ ke heading $90^{\circ}$ memerlukan waktu 54 detik, kecepatan kapal turun dari 20 knots menjadi 13.7 knots, pergerakan lateral haluan kapal bergerak ke kanan 0.1 knot sedangkan pergerakan lateral buritan kapal bergerak ke kiri 8.3 knots dan Rate of Turn $132^{\circ} / \mathrm{min}$ ke kanan, kemiringan kapal ke kiri $13^{\circ}$ dengan jarak tempuh kapal sejauh $0.2 \mathrm{Nm}$. Jarak advanced $0.236 \mathrm{Nm}$ atau 430.7 meter diperoleh dengan mengukur range membujur ke arah $0^{\circ}$ dari titik kapal pada posisi heading $0^{\circ}$ sampai pada garis melintang posisi kapal heading $90^{\circ}$.

Jarak transfer $0.083 \mathrm{Nm}$ atau 153.7 meter diperoleh dengan mengukur range melintang ke arah $270^{\circ}$ dari titik kapal pada posisi heading $90^{\circ}$ sampai pada garis membujur posisi kapal heading $0^{\circ}$. Drift Angle $19.7^{\circ}$ diperoleh dengan mengurangi heading $90^{\circ}$ dengan sudut lintasan titik berat kapal atau pada instrumen GPS pada COG : $70.4^{\circ}$, jarak Tactical Diameter $0.209 \mathrm{Nm}$ atau 387.1 meter yang diperoleh dengan mengukur range melintang ke arah $270^{\circ}$ dari titik kapal pada posisi heading $180^{\circ}$ sampai pada garis membujur posisi kapal heading $0^{\circ}$, dan Steady Turning Diameter atau jarak diameter putar yang 
ditempuh kapal pada kondisi putaran yang tidak banyak melakukan perubahan dengan diameter $0.202 \mathrm{Nm}$ atau 374.1 meter seperti yang ditunjukkan pada Gambar 3.

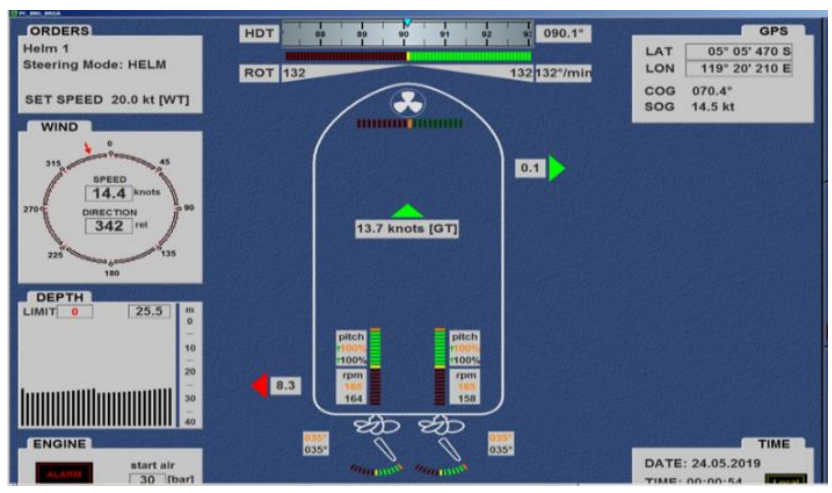

Gambar 1. Jendela monitor, turning cycle kanan pada sudut kemudi $35^{\circ}$

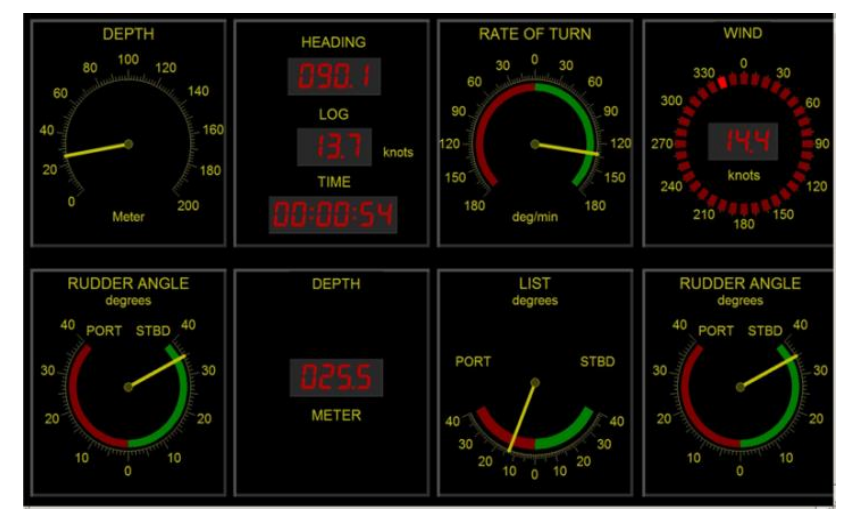

Gambar 2. Jendela instrument monitor control, Turning cycle kanan pada sudut kemudi $3^{\circ}$

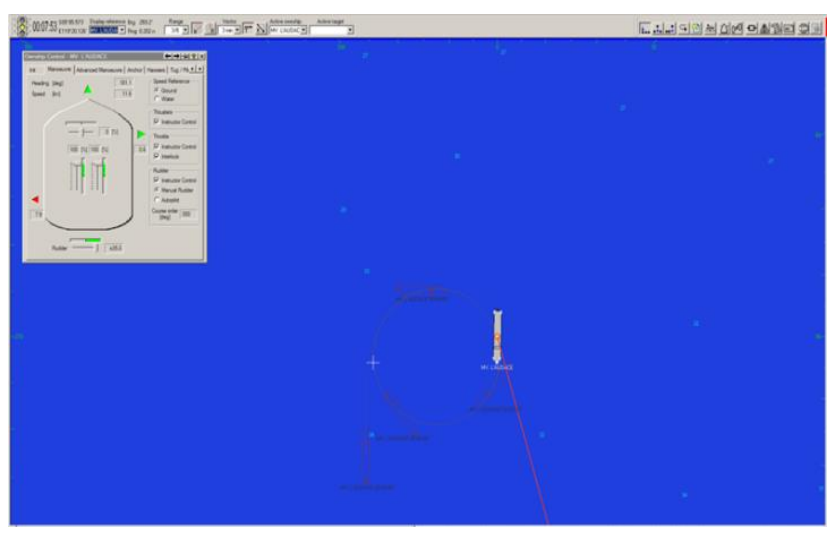

Gambar 3. Posisi kapal pada turning cycle kanan $540^{\circ}$

Begitu pula pada proses simulasi turning cycle yang kedua dengan sudut kemudi $+20^{\circ}$, perubahan pergerakan respon kapal dari heading $0^{\circ} \mathrm{ke}$ heading $90^{\circ}$ memerlukan waktu 67 detik, kecepatan kapal turun dari 20 knots menjadi 15.2 knots, pergerakan lateral haluan kapal bergerak ke kiri 0.3 knot sedangkan pergerakan lateral buritan kapal bergerak ke kiri 6.9 knots dan Rate of Turn $103^{\circ} /$ min ke kanan, kemiringan kapal ke kiri $11^{\circ}$ dengan jarak tempuh kapal sejauh $0.3 \mathrm{Nm}$.

Jarak advanced $0.283 \mathrm{Nm}$ atau 524.1 meter diperoleh dengan mengukur range membujur ke arah $0^{\circ}$ dari titik kapal pada posisi heading $0^{\circ}$ sampai pada garis melintang posisi kapal heading $90^{\circ}$, jarak transfer $0.125 \mathrm{Nm}$ atau 231.5 meter diperoleh dengan mengukur range melintang ke arah $270^{\circ}$ dari titik kapal pada posisi heading $90^{\circ}$ sampai pada garis membujur posisi kapal heading $0^{\circ}$, Drift Angle $15.9^{\circ}$ diperoleh dengan mengurangi heading $91.2^{\circ}$ dengan sudut lintasan titik berat kapal atau pada instrumen GPS pada COG : $75.3^{\circ}$, jarak Tactical Diameter $0.294 \mathrm{Nm}$ atau 544.5 meter yang diperoleh dengan mengukur range melintang ke arah $270^{\circ}$ dari titik kapal pada posisi heading $180^{\circ}$ sampai pada garis membujur posisi kapal heading $0^{\circ}$, dan Steady Turning Diameter atau jarak diameter putar yang ditempuh kapal pada kondisi putaran yang tidak banyak melakukan perubahan dengan diameter $0.281 \mathrm{Nm}$ atau 520.4 meter.

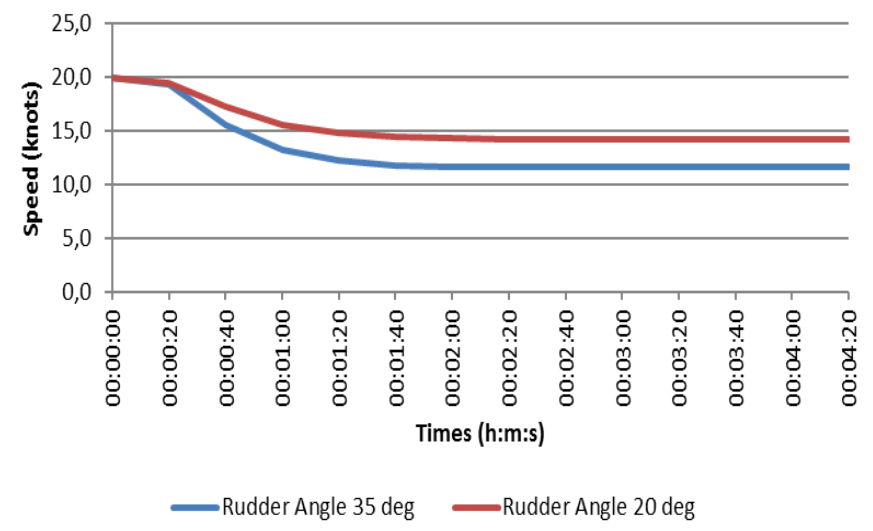

Gambar 4. Karakteristik speed pada turning cycle
kanan

Gambar 4 menunjukkan grafik perubahan speed terhadap times saat Turning cycle kanan pada sudut kemudi $35^{\circ}$ dan $20^{\circ}$ hasil analisa berdasarkan data Tabel 2 dan 3. Saat turning cycle dengan sudut kemudi $35^{\circ}$ terjadi penurunan kecepatan kapal atau kehilangan kecepatan sebesar $42 \%$, sedangkan pada saat turning cycle 
dengan sudut kemudi $20^{\circ}$ terjadi penurunan kecepatan kapal atau kehilangan kecepatan sebesar $29 \%$.

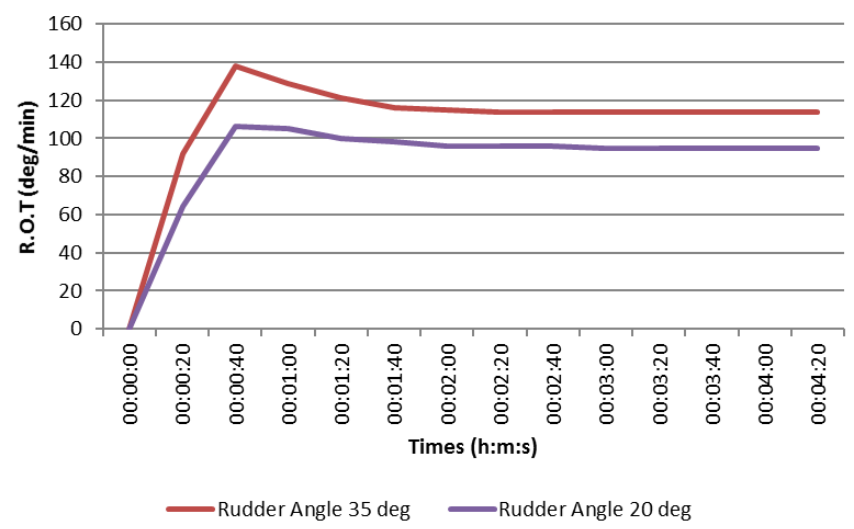

Gambar 5. Karakteristik rate of turn pada turning cycle kanan

Tabel 2. Data turning cycle kanan pada sudut kemudi $3^{\circ}$

\begin{tabular}{cccccc}
\hline $\begin{array}{c}\text { Time } \\
(\mathbf{s})\end{array}$ & $\begin{array}{c}\text { Speed } \\
(\mathbf{k n})\end{array}$ & $\begin{array}{c}\text { Heading } \\
(\mathbf{d e g})\end{array}$ & $\begin{array}{c}\text { COG } \\
(\mathbf{d e g})\end{array}$ & $\begin{array}{c}\text { R.O.T } \\
(\mathbf{d e g} / \\
\mathbf{m i n})\end{array}$ & $\begin{array}{c}\text { Drirt } \\
\text { Angle } \\
(\mathbf{d e g})\end{array}$ \\
\hline $00: 00$ & 20,0 & 0,0 & 0,0 & 0 & 0,0 \\
$00: 20$ & 19,3 & 13,5 & 4,3 & 92 & 9,2 \\
$00: 40$ & 15,6 & 56,3 & 40,0 & 138 & 16,3 \\
$01: 00$ & 13,2 & 102,6 & 83,8 & 129 & 18,8 \\
$01: 20$ & 12,2 & 144,5 & 126,1 & 121 & 18,4 \\
$01: 40$ & 11,8 & 185,7 & 166,7 & 116 & 19,0 \\
$02: 00$ & 11,7 & 223,7 & 205,4 & 115 & 18,3 \\
$02: 20$ & 11,6 & 262,8 & 244,1 & 114 & 18,7 \\
$02: 40$ & 11,6 & 300,7 & 282,7 & 114 & 18,0 \\
$03: 00$ & 11,6 & 339,2 & 320,6 & 114 & 18,6 \\
$03: 20$ & 11,6 & 17,2 & 358,6 & 114 & 18,6 \\
$03: 40$ & 11,6 & 55,1 & 36,9 & 114 & 18,2 \\
$04: 00$ & 11,6 & 93,1 & 75,2 & 114 & 17,9 \\
$04: 20$ & 11,6 & 132,3 & 113,4 & 114 & 18,9 \\
\hline
\end{tabular}

Gambar 5 menunjukkan grafik hasil analisa ROT terhadap times berdasarkan data Tabel 2 dan 3 dari hasil Turning cycle kanan pada sudut kemudi $35^{\circ}$ dan $20^{\circ}$, bahwa pada saat turning cycle dengan sudut kemudi $35^{\circ}$ terjadi peningkatan turn rate hingga $138^{\circ}$ /menit pada waktu ke 40 detik, kemudian mulai terjadi penurunan turn rate $114 \%$ menit hingga pada waktu 2 menit dan 20 detik dan selanjutnya turn rate kapal menjadi konstan pada waktu Steady
Turning Diameter, begitu pula pada saat turning cycle dengan sudut kemudi $20^{\circ}$ terjadi peningkatan turn rate hingga $106 \%$ menit pada waktu ke 40 detik, kemudian mulai terjadi penurunan turn rate $95 \%$ menit hingga pada waktu 2 menit dan 20 detik dan selanjutnya turn rate kapal menjadi konstan pada waktu Steady Turning Diameter.

Tabel 3. Data turning cycle kanan pada sudut kemudi $20^{\circ}$

\begin{tabular}{cccccc}
\hline $\begin{array}{c}\text { Time } \\
(\mathbf{s})\end{array}$ & $\begin{array}{c}\text { Speed } \\
(\mathbf{k n})\end{array}$ & $\begin{array}{c}\text { Heading } \\
(\mathbf{d e g})\end{array}$ & $\begin{array}{c}\text { COG } \\
(\mathbf{d e g})\end{array}$ & $\begin{array}{c}\text { R.O.T } \\
(\mathbf{d e g} / \\
\text { min) }\end{array}$ & $\begin{array}{c}\text { Drirt } \\
\text { Angle } \\
(\mathbf{d e g})\end{array}$ \\
\hline $00: 00$ & 20,0 & 0,0 & 0,0 & 0 & 0,0 \\
$00: 20$ & 19,5 & 11,1 & 3,2 & 64 & 7,9 \\
$00: 40$ & 17,3 & 42,2 & 27,9 & 106 & 14,3 \\
$01: 00$ & 15,6 & 78,3 & 62,7 & 105 & 15,6 \\
$01: 20$ & 14,8 & 112,5 & 98,1 & 100 & 14,4 \\
$01: 40$ & 14,4 & 146,6 & 131,3 & 98 & 15,3 \\
$02: 00$ & 14,3 & 178,7 & 164,1 & 96 & 14,6 \\
$02: 20$ & 14,2 & 211,6 & 196,5 & 96 & 15,1 \\
$02: 40$ & 14,2 & 244,7 & 230,1 & 96 & 14,6 \\
$03: 00$ & 14,2 & 276,0 & 260,9 & 95 & 15,1 \\
$03: 20$ & 14,2 & 308,0 & 293,0 & 95 & 15,0 \\
$03: 40$ & 14,2 & 340,1 & 325,1 & 95 & 15,0 \\
$04: 00$ & 14,2 & 12,2 & 356,9 & 95 & 15,3 \\
$04: 20$ & 14,2 & 44,4 & 29,2 & 95 & 15,2 \\
\hline
\end{tabular}

Tabel 4. Data performance turning cycle kanan pada sudut kemudi $35^{\circ} \& 2^{\circ}$

\begin{tabular}{ccccccc}
\hline $\begin{array}{c}\text { Rudder } \\
\text { Angle } \\
(\mathbf{d e g})\end{array}$ & $\begin{array}{c}\text { Time } \\
\mathbf{9 0}^{\circ} \\
(\mathbf{s})\end{array}$ & $\begin{array}{c}\text { Advan } \\
\mathbf{c e} \\
(\mathbf{m})\end{array}$ & $\begin{array}{c}\text { Transf } \\
\mathbf{( m )}\end{array}$ & $\begin{array}{c}\text { Time } \\
\mathbf{1 8 0}^{\circ} \\
(\mathbf{s})\end{array}$ & $\begin{array}{c}\text { Tactic } \\
\text { al dia. } \\
(\mathbf{m})\end{array}$ & $\begin{array}{c}\text { Steady } \\
\text { turning } \\
\mathbf{d i a} . \\
(\mathbf{m})\end{array}$ \\
\hline $35^{\circ}$ & 54 & 430,7 & 153,7 & 98 & 387,1 & 374,1 \\
$20^{\circ}$ & 67 & 524,1 & 231,5 & 121 & 544,5 & 520,4 \\
\hline
\end{tabular}

Pada Tabel 4 merupakan data hasil simulasi terhadap Performance Turning Cycle ke kanan pada sudut kemudi $35^{\circ}$ dan $20^{\circ}$, sehingga jarak Advanced dan Tactical Diameter untuk kapal model masih sesuai kriteria standar yang dipersyaratkan oleh IMO's Resolution MSC 137 (76) yaitu Advanced < $4.5 \mathrm{Lbp}$ dan Tactical Diameter $<5.0 \mathrm{Lbp}$. 


\subsection{Hasil Simulasi Maneuver Zig-Zag}

Data pada Tabel 5 dan 6 diperoleh dari hasil pengamatan pada instrument simulasi maneuver zig-zag $20^{\circ} / 20^{\circ}$ dan zig-zag $10^{\circ} / 10^{\circ}$ seperti yang ditunjukkan pada Gambar 5, 6 dan 7 .

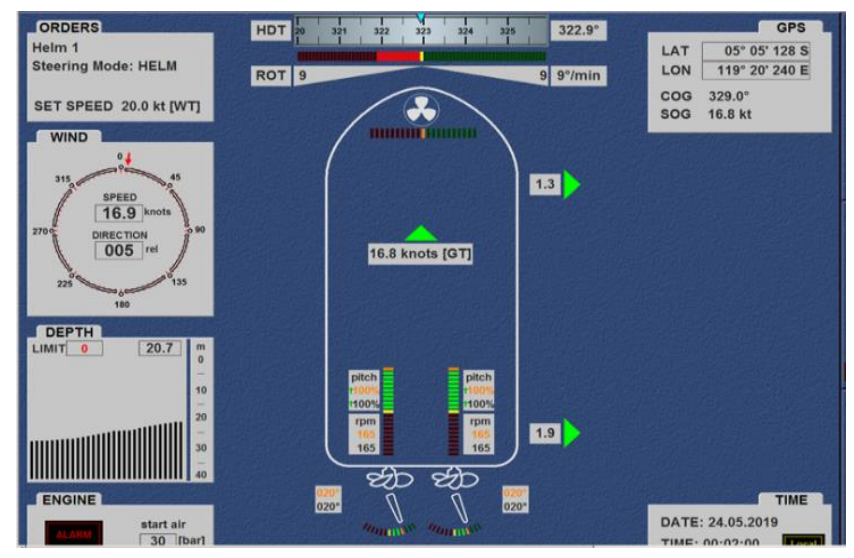

Gambar 5. Jendela monitor, Zig-zag $20^{\circ} / \mathbf{2 0}^{\circ}$ ( st $^{\text {overshoot })}$

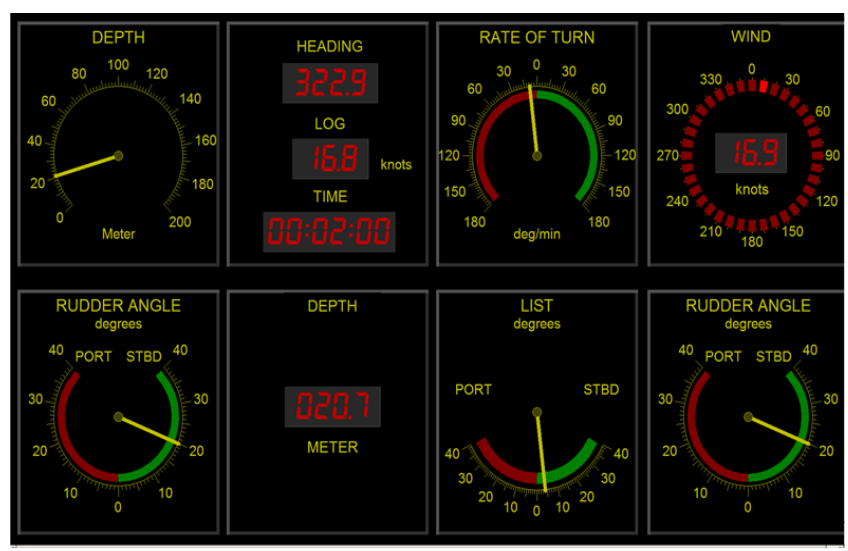

Gambar 6. Jendela instrument monitor control zig-zag $20^{\circ} / 20^{\circ}\left(1^{\text {st }}\right.$ overshoot $)$

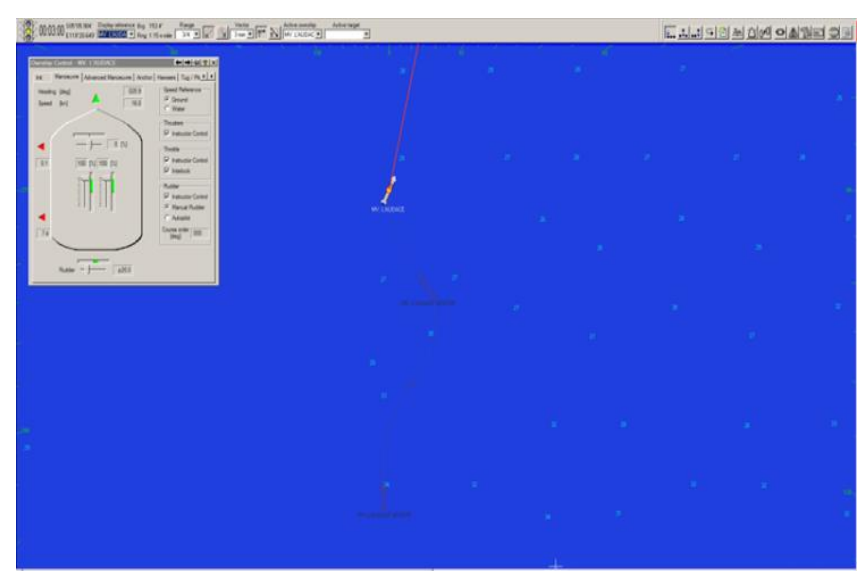

Gambar 7. Posisi kapal pada zig-zag $20^{\circ} / 20^{\circ}\left(2^{n d}\right.$ overshoot)
Pada Gambar 8 dan 9 menunjukkan karakteristik rudder angle dan heading terhadap times dan speed berdasarkan Tabel 5 dan 6 dari hasil rekapitulasi data respon kapal pada Zig-zag test $20^{\circ} / 20^{\circ}$ dan Zig-zag test $10^{\circ} / 10^{\circ}$.

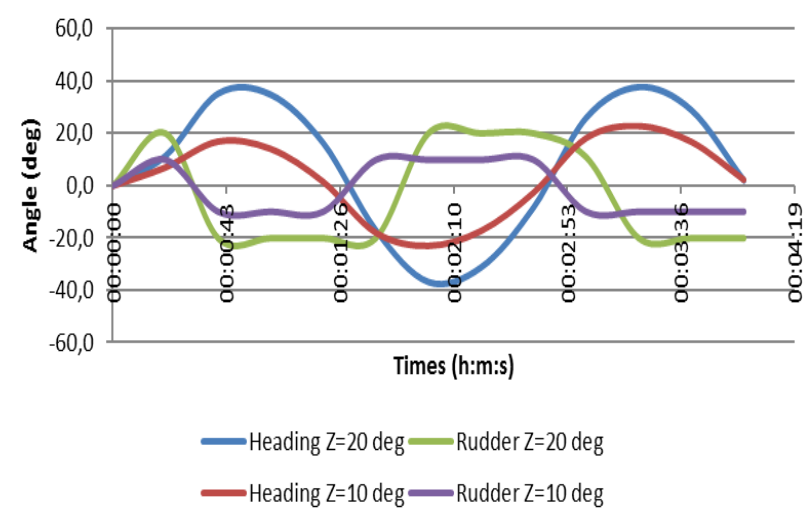

Gambar 8. Karakteristik rudder dan heading angle pada zig-zag maneuver

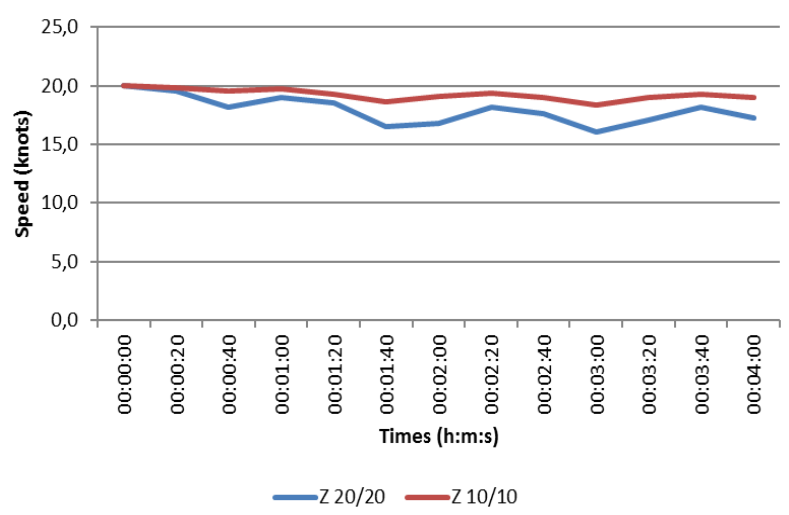

Gambar 9. Karakteristik speed zig-zag maneuver

Berdasarkan grafik pada Gambar 8 dan 9 dapat dianalisa bahwa pada saat zig-zag maneuver test $20^{\circ} / 20^{\circ}$, $1^{\text {st }}$ overshoot sebesar $18^{\circ}$ terjadi selama 22 detik begitu pula dengan pada $2^{\text {nd }}$ overshoot sebesar $18^{\circ}$ terjadi selama 22 detik dengan waktu perod of oscillation sebesar 157 detik dan terjadi penurunan kecepatan sebesar $9 \%$. Selanjutnya pada zig-zag maneuver test $10^{\circ} / 10^{\circ}$, $1^{\text {st }}$ overshoot sebesar $7^{\circ}$ terjadi selama 19 detik dan pada $2^{\text {nd }}$ overshoot sebesar $13^{\circ}$ terjadi selama 27 detik dengan waktu perod of oscillation sebesar 160 detik serta terjadi penurunan kecepatan sebesar $2.5 \%$. Pada saat rate of turn semakin bertambah, speed kapal semakin berkurang dan pada saat rate of turn semakin berkurang, speed kapal semakin bertambah, 
sehingga rate of turn berbanding terbalik dengan speed.

Tabel 5. Data zig-zag $20^{\circ} / 20^{\circ}$

\begin{tabular}{ccccc}
\hline $\begin{array}{c}\text { Time } \\
(\mathbf{s})\end{array}$ & $\begin{array}{c}\text { Rudder } \\
(\mathbf{d e g})\end{array}$ & $\begin{array}{c}\text { Heading } \\
(\mathbf{d e g})\end{array}$ & $\begin{array}{c}\text { Speed } \\
(\mathbf{k n})\end{array}$ & $\begin{array}{c}\text { R.O.T } \\
(\mathbf{d e g} / \mathbf{m i n})\end{array}$ \\
\hline $00: 00: 00$ & 0 & 0,0 & 20,0 & 0 \\
00:00:20 & 20 & 11,3 & 19,5 & 65 \\
00:00:40 & -20 & 35,2 & 18,2 & 28 \\
00:01:00 & -20 & 34,8 & 19,0 & -26 \\
00:01:20 & -20 & 16,2 & 18,5 & -86 \\
00:01:40 & -20 & $-17,2$ & 16,5 & -106 \\
00:02:00 & 20 & $-37,1$ & 16,8 & -9 \\
00:02:20 & 20 & $-31,5$ & 18,2 & 40 \\
00:02:40 & 20 & $-8,5$ & 17,6 & 94 \\
00:03:00 & 11 & 25,9 & 16,0 & 99 \\
00:03:20 & -20 & 37,7 & 17,1 & -3 \\
00:03:40 & -20 & 28,9 & 18,2 & -50 \\
00:04:00 & -20 & 1,9 & 17,2 & -100 \\
\hline
\end{tabular}

Tabel 6. Data zig-zag $10^{\circ} / 10^{\circ}$

\begin{tabular}{ccccc}
\hline $\begin{array}{c}\text { Time } \\
\text { (s) }\end{array}$ & $\begin{array}{c}\text { Rudder } \\
(\mathbf{d e g})\end{array}$ & $\begin{array}{c}\text { Heading } \\
(\mathbf{d e g})\end{array}$ & $\begin{array}{c}\text { Speed } \\
(\mathbf{k n})\end{array}$ & $\begin{array}{c}\text { R.O.T } \\
(\mathbf{d e g} / \mathbf{m i n})\end{array}$ \\
\hline 00:00:00 & 0 & 0,0 & 20,0 & 0 \\
00:00:20 & 10 & 7,0 & 19,8 & 37 \\
00:00:40 & -10 & 16,9 & 19,5 & 9 \\
00:01:00 & -10 & 14,1 & 19,7 & -24 \\
00:01:20 & -10 & 1,5 & 19,3 & -50 \\
00:01:40 & 10 & $-17,9$ & 18,6 & -36 \\
00:02:00 & 10 & $-22,9$ & 19,1 & 2 \\
00:02:20 & 10 & $-17,2$ & 19,4 & 31 \\
00:02:40 & 10 & $-2,6$ & 19,0 & 56 \\
00:03:00 & -10 & 18,2 & 18,3 & 34 \\
00:03:20 & -10 & 22,8 & 19,0 & -3 \\
00:03:40 & -10 & 16,8 & 19,3 & -32 \\
00:04:00 & -10 & 2,3 & 19 & -56 \\
\hline
\end{tabular}

\subsection{Hasil Simulasi Self Turning Basin}

Salah satu dari lima belas model variasi simulasi self turning basin, yang ditampilkan adalah variasi III yaitu kemudi kiri pada posisi sudut $30^{\circ}$ ke kanan dan kemudi kanan pada posisi sudut $30^{\circ}$ ke kiri $\left(\right.$ P. $+30^{\circ} \&$ S. $\left.-30^{\circ}\right)$, dimana Port side Engine Full Ahead dan Starboard side Engine Full Astern (rpm konstan) seperti yang ditunjukkan pada Gambar 10 dan 11.

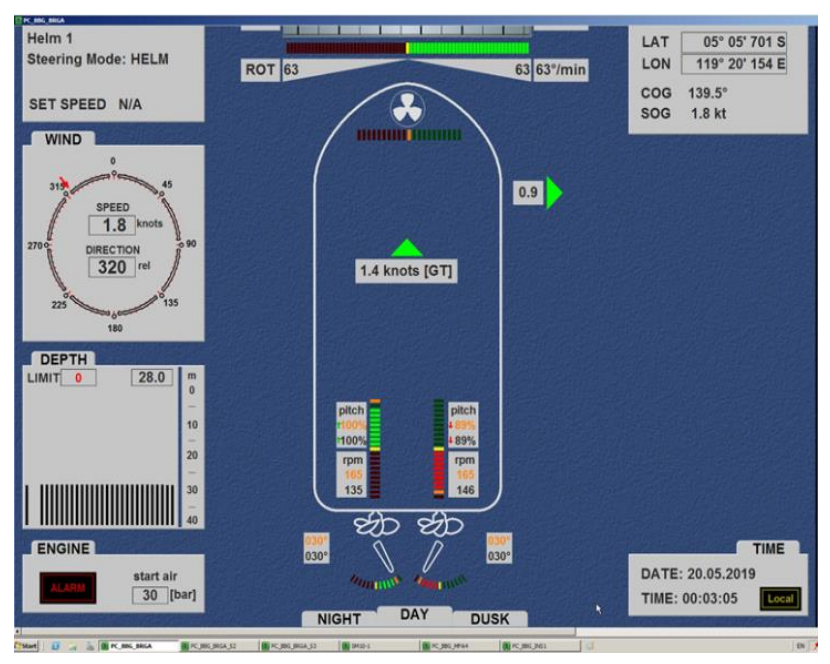

Gambar 10. Jendela monitor, Variasi III (P.+30º S.-30 $)$

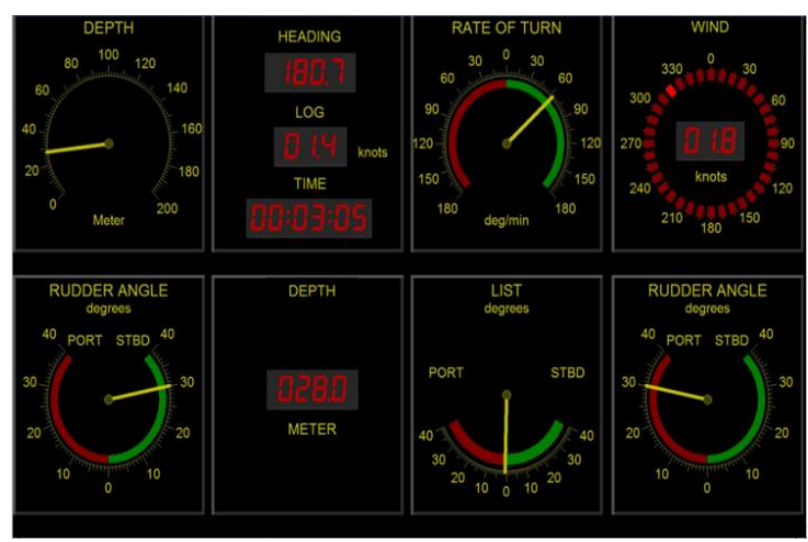

Gambar 11. Jendela instrument monitor control, variasi III $\left(\right.$ P. $^{+30^{\circ}} \&$ S. $\left.-3^{\circ}\right)$

Adapun hasil dari respon kapal pada self turning basin variasi III $\left(\mathrm{P} .+30^{\circ} \& \mathrm{~S} .-30^{\circ}\right)$ dapat dilihat pada Gambar 12.

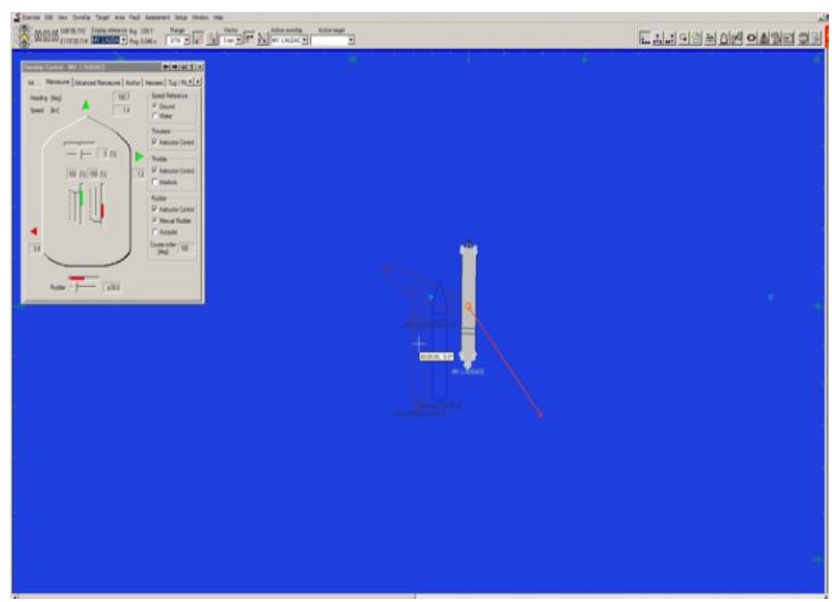

Gambar 12. Posisi kapal pada turning basin variasi III $\left(\mathrm{P} .+30^{\circ} \&\right.$ S. $\left.-30^{\circ}\right)$ 
Model variasi III $\quad\left(\mathrm{P} .+30^{\circ}\right.$ \& $\quad$ S. $\left.-30^{\circ}\right)$ menunjukkan pergerakan kapal bergerak maju dengan kecepatan 1.4 knots, kemudian pergerakan lateral haluan kapal bergerak ke kanan dengan kecepatan 1.2 knot dan pergerakan lateral buritan kapal bergerak ke kiri dengan kecepatan 3.5 knot dalam waktu 3.08 menit mengakibatkan posisi kapal berada pada jarak 0.046 mile dari posisi awal dengan sudut bearing 239.1 derajat dengan jarak tempuh 0.1 mil sehingga menghasilkan rata rata perputaran kapal menjadi 63 derajat/menit.

Dari hasil data yang diperoleh pada data Tabel 7, 8 dan 9, berikut Gambar 13, 14, 15 dan 16 menunjukkan grafik untuk membedakan karakteristik respon kapal terhadap hubungan variasi sudut kemudi dengan rata rata perputaran kapal (ROT), waktu (Times), kecepatan kapal (Speed) dan Jarak titik putar (Range).

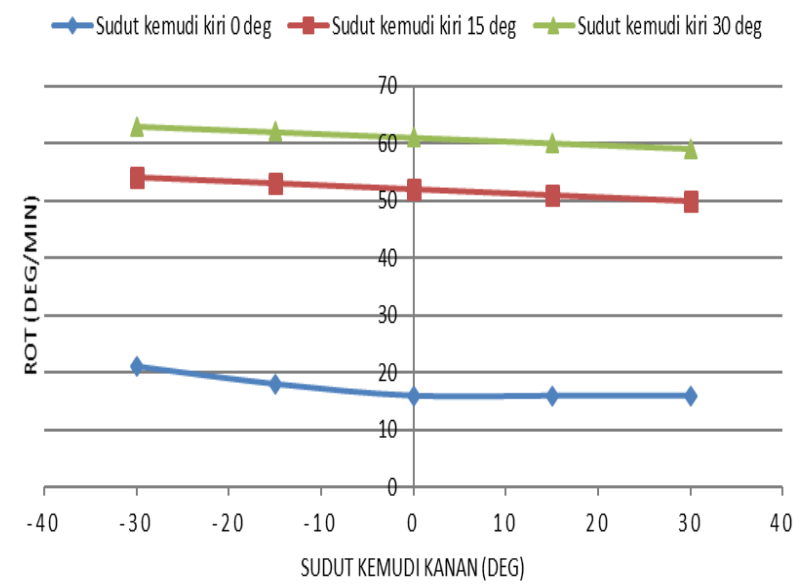

Gambar 13. Karakteristik ROT pada turning basin kanan

Gambar 13, menunjukkan hubungan rata rata perputaran kapal (ROT) terhadap variasi sudut kemudi, dapat dinyatakan bahwa :

- Pada ROT variasi I, kemudi kiri diposisikan pada sudut tetap $0^{\circ}$ dan kemudi kanan diposisikan dari sudut $0^{\circ}$ sampai dengan sudut $30^{\circ}$ atau diarahkan ke kanan, tidak dapat menaikan ROT, namun sebaliknya apabila diposisikan dari sudut $0^{\circ}$ sampai dengan sudut $-30^{\circ}$ atau diarahkan ke kiri dapat menaikan ROT. Semakin besar sudut kemudi kanan diarahkan ke kiri semakin naik ROT.

- Pada ROT variasi II, kemudi kiri diposisikan pada sudut tetap $15^{\circ}$ dan kemudi kanan diposisikan dari sudut $30^{\circ}$ sampai dengan sudut $-30^{\circ}$ atau diarahkan dari kanan ke kiri akan dapat menaikan ROT. Semakin besar sudut kemudi kanan diarahkan ke kanan (+) maka semakin turun ROT, sebaliknya semakin besar sudut kemudi kanan diarahkan ke kiri (-) maka semakin naik ROT.

- Pada ROT variasi III, kemudi kiri diposisikan pada sudut tetap $30^{\circ}$ dan kemudi kanan diposisikan dari sudut $30^{\circ}$ sampai dengan sudut $-30^{\circ}$ atau diarahkan dari kanan ke kiri akan dapat menaikan ROT. Semakin besar sudut kemudi kanan diarahkan ke kanan (+) maka semakin turun ROT, sebaliknya semakin besar sudut kemudi kanan diarahkan ke kiri (-) maka semakin naik ROT.

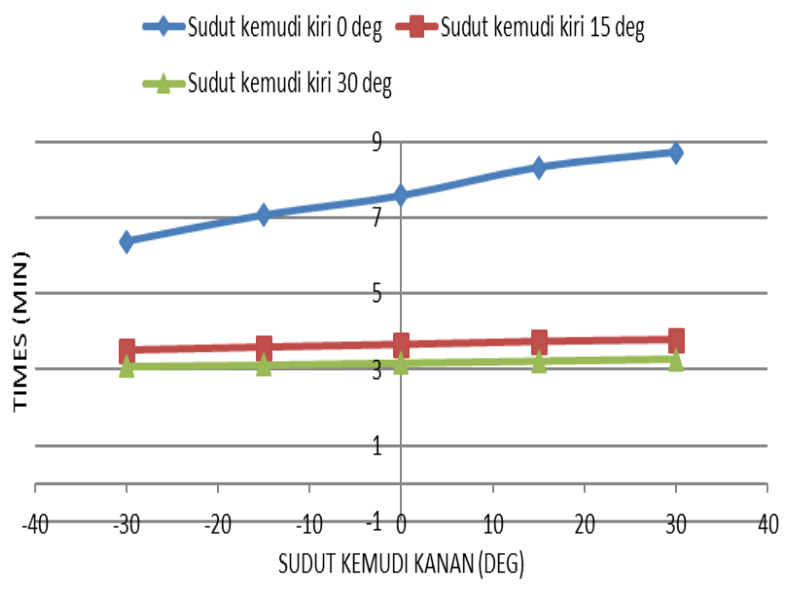
Gambar 14. Karakteristik times pada turning basin
kanan

Gambar 14, menunjukkan hubungan antara waktu yang diperlukan untuk memutar kapal (Times) terhadap variasi sudut kemudi, dapat dinyatakan bahwa :

Pada Times variasi I, II dan III, dimana kemudi kiri yang diposisikan pada sudut tetap $0^{\circ}$, $15^{\circ}, 30^{\circ}$ dan kemudi kanan diposisikan dari sudut $30^{\circ}$ sampai dengan sudut $-30^{\circ}$ atau diarahkan dari kanan ke kiri akan memperkecil waktu. Semakin besar sudut kemudi kanan diarahkan ke kiri (-) semakin rendah waktu yang diperlukan.

Gambar 15 menunjukkan hubungan antara Speed yang diperoleh terhadap variasi sudut kemudi. Dapat dinyatakan bahwa pada Speed variasi I, II dan III, dimana kemudi kiri yang diposisikan pada sudut tetap $0^{\circ}, 15^{\circ}, 30^{\circ}$ dan 
kemudi kanan diposisikan dari sudut $30^{\circ}$ sampai dengan sudut $-30^{\circ}$ atau diarahkan dari kanan ke kiri akan memperlambat kecepatan. Semakin besar sudut kemudi kanan diarahkan ke kiri (-) semakin lambat kecepatan kapal.

\section{$\rightarrow$ Sudut kemudi kiri 0 deg $=$ Sudut kemudi kiri $15 \mathrm{deg} \rightarrow$ Sudut kemudi kiri $30 \mathrm{de \xi}$}

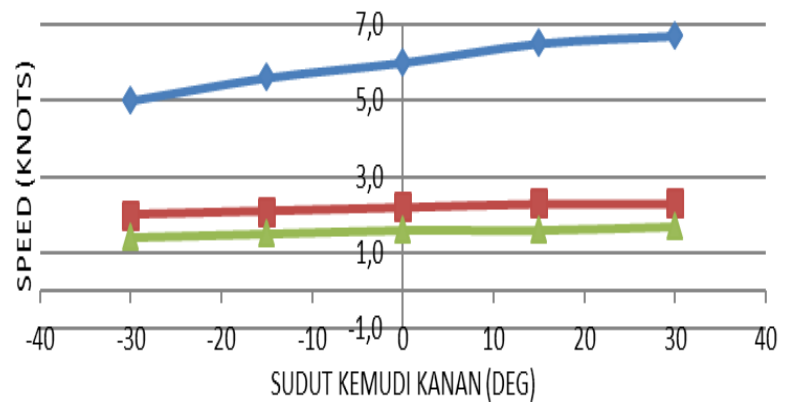

Gambar 15. Karakteristik speed pada turning basin kanan

Gambar 16, menunjukkan hubungan antara jarak titik putar kapal yang diperoleh (Range) terhadap variasi sudut kemudi, dapat dinyatakan bahwa pada Range variasi I, II dan III, dimana kemudi kiri yang diposisikan pada sudut tetap $0^{\circ}$, $15^{\circ}, 30^{\circ}$ dan kemudi kanan diposisikan dari sudut $30^{\circ}$ sampai dengan sudut $-30^{\circ}$ atau diarahkan dari kanan ke kiri akan mempependek jarak titik putar. Semakin besar sudut kemudi kanan diarahkan ke kiri (-) maka semakin pendek jarak titik putar kapal.

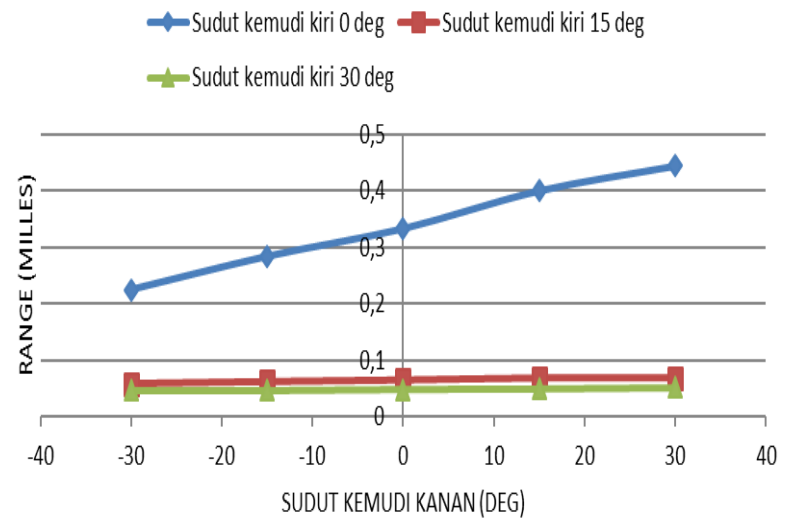

Gambar 16. Karakteristik range pada turning basin kanan
Berikut Tabel 7, 8 dan 9, menunjukkan hasil rekapitulasi data respon kapal terhadap simulasi self turning basin yang diperoleh dari pengamatan pada instrument sebagai berikut :

Tabel 7. Data model variasi $\mathbf{I}$, sudut kemudi $\mathbf{P}=0^{\circ}$; $\mathbf{S}=$ Variasi

\begin{tabular}{|c|c|c|c|c|c|}
\hline $\begin{array}{l}\text { Port Rudder } \\
\text { Angle (Deg) }\end{array}$ & 0 & 0 & 0 & 0 & 0 \\
\hline $\begin{array}{l}\text { Starboard Rudder } \\
\text { Angle (Deg) }\end{array}$ & -30 & -15 & 0 & 15 & 30 \\
\hline$L O G(K t)$ & 5,0 & 5,6 & 6,0 & 6,5 & 6,7 \\
\hline $\begin{array}{l}\text { Bow Lateral speed } \\
(k t)\end{array}$ & 0,0 & $-0,1$ & $-0,1$ & $-0,1$ & $-0,1$ \\
\hline $\begin{array}{l}\text { Stern Lateral } \\
\text { speed }(k t)\end{array}$ & $-1,6$ & $-1,4$ & $-0,3$ & $-1,3$ & $-1,3$ \\
\hline Times (Minutes) & 6,38 & 7,07 & 7,58 & 8,33 & 8,73 \\
\hline Range (Nm) & 0,225 & 0,284 & 0,333 & 0,400 & 0,444 \\
\hline Bearing (Deg) & 292,6 & 297,6 & 298,0 & 297,8 & 296,8 \\
\hline $\begin{array}{l}\text { Distance Run } \\
(\mathrm{Nm})\end{array}$ & 0,3 & 0,4 & 0,5 & 0,6 & 0,6 \\
\hline ROT (Deg/min.) & 21 & 18 & 16 & 16 & 16 \\
\hline
\end{tabular}

Tabel 8. Data model variasi II, sudut kemudi $P=$ $15^{\circ} ; \mathrm{S}=$ Variasi

\begin{tabular}{lccccc}
\hline $\begin{array}{l}\text { Port Rudder } \\
\text { Angle (Deg) }\end{array}$ & 15 & 15 & 15 & 15 & 15 \\
$\begin{array}{l}\text { Starboard Rudder } \\
\text { Angle (Deg) }\end{array}$ & -30 & -15 & 0 & 15 & 30 \\
\hline $\begin{array}{l}\text { LOG (Kt) } \\
\text { Bow Lateral speed }\end{array}$ & 2,0 & 2,1 & 2,2 & 2,3 & 2,3 \\
(kt) & 1,0 & 0,9 & 0,9 & 0,9 & 0.9 \\
$\begin{array}{l}\text { Stern Lateral } \\
\text { speed (kt) }\end{array}$ & $-3,1$ & $-3,0$ & $-3,0$ & $-2,9$ & $-2,9$ \\
$\begin{array}{l}\text { Times (Minutes) } \\
\text { Range (Nm) }\end{array}$ & 3,5 & 3,58 & 3,65 & 3,73 & 3,78 \\
$\begin{array}{l}\text { Bearing (Deg) } \\
\text { Distance Run }\end{array}$ & 0,058 & 0,062 & 0,065 & 0,069 & 0,069 \\
(Nm) & 255,2 & 257,1 & 259,7 & 260,6 & 261,4 \\
ROT(Deg/min.) & 54 & 0,1 & 0,1 & 0,1 & 0,1 \\
\hline
\end{tabular}


Tabel 9. Data model variasi III, sudut kemudi $P=$ $30^{\circ} ; \mathbf{S}=$ Variasi

\begin{tabular}{lccccc}
\hline $\begin{array}{l}\text { Port Rudder } \\
\text { Angle (Deg) }\end{array}$ & 30 & 30 & 30 & 30 & 30 \\
$\begin{array}{l}\text { Starboard Rudder } \\
\text { Angle (Deg) }\end{array}$ & -30 & -15 & 0 & 15 & 30 \\
\hline $\begin{array}{l}\text { LOG (Kt) } \\
\text { Bow Lateral speed } \\
\text { (kt) }\end{array}$ & 1,4 & 1,5 & 1,6 & 1,6 & 1,7 \\
$\begin{array}{l}\text { Stern Lateral } \\
\text { speed (kt) }\end{array}$ & $-3,5$ & $-3,5$ & $-3,4$ & $-3,4$ & $-3,4$ \\
$\begin{array}{l}\text { Times (Minutes) } \\
\text { Range (Nm) }\end{array}$ & 3,08 & 3,12 & 3,17 & 3,22 & 3,27 \\
$\begin{array}{l}\text { Bearing (Deg) } \\
\text { Distance Run }\end{array}$ & 239,1 & 243,7 & 244,1 & 245,3 & 247,7 \\
(Nm) & 0,1 & 0,1 & 0,1 & 0,1 & 0,1 \\
ROT (Deg/min.) & 63 & 62 & 61 & 60 & 59 \\
\hline
\end{tabular}

\section{Kesimpulan}

Simulasi Self Turning Basin dengan metode mesin kiri maju penuh dan mesin kanan mundur penuh (rpm konstan) dengan beberapa variasi sudut kemudi, dapat diambil suatu kesimpulan sebagai berikut :

- Pada kemudi kanan, memposisikan sudut kemudi pada arah kanan atau positif (+) dapat mengurangi Rate of Turn (R.O.T), memperlambat waktu putar, menambah kecepatan kapal dan memperpanjang jarak putar kapal.

- Sudut kemudi yang menunjukkan karakteristik respon putar kapal terhadap gerakan Surging, Swaying dan Yawing adalah yang menunjukkan ROT tertinggi, Times terpendek, Speed terendah dan Range terpendek.

\section{Referensi}

[1] M. Ridwan Utina. (2009). Simulasi Manuver Turning Kapal Ferry Penumpang. Jurnal Wave, UPT BPPH BPPT Vol.3 No. 2.

[2] Daeng Paroka, Andi Haris Muhammad and Syamsul Asri. (2016). Maneuverability of Ship with Small Draught in Steady Wind. Department of Naval Architect, Faculty of Engineering - UNHAS.

[3] Maritime Safety Committee on Ship Maneuverability of International Maritime Organization (IMO), MSC 76/23, Resolution MSC. 137(76), London (2002).

[4] Cahaya Fajar Budi Hartanto. (2018). Pemanfaatan Simulator Dalam Meningkatkan Pengetahuan dan Keterampilan Bernavigasi Taruna Akademi Pelayaran Niaga Indonesia. Jurnal Mitra Pendidikan (JMP Online) Vol. 2 No. 4.

[5] Description of Ship Model RORO04L Roll-on Roll-off Ship L'Audace Full Loaded Version 6 - Kongsberg Maritime (2012).

[6] Kongsberg Maritime AS. (2011). Polaris Ship's Bridge Simulator - Technical Manual - Section 5b Instrumentation. 